This is the peer reviewed version of the following article: Fernandez-Montalvo, J., Lopez-Goñi, J. J., Azanza, P. and Cacho, R. (2014), Gender differences in drug-addicted patients in a clinical treatment center of Spain. Am J Addict, 23: 399-406. doi:10.1111/j.1521-0391.2013.12117.x, which has been published in final form at https://doi.org/10.1111/j.1521-0391.2013.12117.x. This article may be used for noncommercial purposes in accordance with Wiley Terms and Conditions for SelfArchiving.

\title{
Gender differences in drug-addicted patients in a clinical treatment center of Spain
}

Running tittle: Gender and addictions

Javier Fernandez-Montalvo (Ph.D.) ${ }^{1}$, José J. Lopez-Goñi ${ }^{1}$ (Ph.D.), Paula Azanza ${ }^{1}$ BSc and Raul Cacho ${ }^{1}$ (Ph.D.)

${ }^{1}$ Departamento de Psicologia y Pedagogia. Universidad Pública de Navarra. Pamplona (Spain)

Corresponding author:

Javier Fernandez-Montalvo

Departamento de Psicología y Pedagogía

Universidad Pública de Navarra

Campus de Arrosadía s/n

31006 Pamplona (Spain)

Phone: +34 948169830

Fax: +34948169891

E-mail: fernandez.montalvo@unavarra.es

Fernández-Montalvo, J., López-Goñi, J. J., Azanza, P. y Cacho, R. (2014). Gender differences in drug-addicted patients in treatment. The American Journal on

Addictions, 23, 399-406

http://onlinelibrary.wiley.com/doi/10.1111/j.1521-0391.2013.12117.x/abstract 
Abstract:

Background and objectives: This study explored the characteristics of a representative sample of patients who were addicted to drugs and analyzed the differential profile of addicted women and men. Methods: A sample of 195 addicted patients (95 female and 100 male) who sought outpatient treatment in a Spanish clinical center was assessed. Information on sociodemographic, consumption and associated characteristics was collected using the European Addiction Severity Index (EuropASI). Results: The results showed statistically significant differences between groups. Demographically, the differences were centered on employment, with more labor problems in the female group. Regarding addiction severity, the EuropASI results showed statistically significant differences in both the Interviewer Severity Ratings (ISR) and Composite Scores (CS). Women experienced more severe impacts in the medical, family social and psychiatric areas. By contrast addicted men had more severe legal problems than addicted females did. Conclusions: According to these results, women who seek outpatient treatment in a clinical center presented with a more severe addiction problem than men did. Moreover, they reported more significant maladjustment in the various aspects of life explored.

Keywords: addiction; gender; woman; differential profile; assessment

Fernández-Montalvo, J., López-Goñi, J. J., Azanza, P. y Cacho, R. (2014). Gender differences in drug-addicted patients in treatment. The American Journal on

Addictions, 23, 399-406

http://onlinelibrary.wiley.com/doi/10.1111/j.1521-0391.2013.12117.x/abstract 


\section{Background and objectives}

In recent years, attention has been focused on gender differences in the treatment of substance dependence. Although several studies exploring gender-differences have been carried out, ${ }^{1,2}$ their results are far from conclusive. Most existing studies consist of clinical samples obtained from patients seeking treatment. This implies an overrepresentation of men, so the results of these studies must be generalized with caution. ${ }^{2,3}$ The profiles of men and women with substance abuse or dependence are not necessarily equal. ${ }^{4-9}$ The development of, the motivations for and the consequences of substance abuse do not necessarily coincide for both sexes. This aspect is of great importance because these factors have a direct impact on the appropriate clinical treatment of the problem. ${ }^{3,5,10}$

Several factors contribute to the low number of female addicts represented in the literature. First, from an epidemiological perspective, a smaller proportion of women have drug problems. Second, from a sociocultural perspective, addiction in women is more socially stigmatized than addiction in men, and this hinders women's search for therapeutic assistance. ${ }^{2,5}$ However, this trend has been changing in recent years. In fact, some research shows that women consume the same amount of drugs and alcohol than men, ${ }^{6,11}$ although specific characteristics differentiate women's substance use from men’s. ${ }^{3}$

The studies that have focused on addiction in women have shown interesting results. It is known, for example, that women are more vulnerable at all stages of the addiction process, both biologically and socially. ${ }^{11-13}$ Research also shows that women begin using substances later than men do; ${ }^{7,14}$ however, they develop more severe addictions in terms of consumption ${ }^{5,10}$ and the associated psychopathological symptomatology (primarily anxiety and mood disorders).,4,8,15-19 Moreover, women's

Fernández-Montalvo, J., López-Goñi, J. J., Azanza, P. y Cacho, R. (2014). Gender differences in drug-addicted patients in treatment. The American Journal on

Addictions, 23, 399-406

http://onlinelibrary.wiley.com/doi/10.1111/j.1521-0391.2013.12117.x/abstract 
addictions are also associated with a greater impact on their family, social life and employment. ${ }^{3,8,20}$ This further complicates the clinical picture that addicted women present.

In comparison, men tend to have more legal problems arising from substance consumption and a higher rate of antisocial personality disorder. ${ }^{7,8,19,20}$ However, the results related to the differential presentation of personality disorders according to gender are very heterogeneous, and the results vary depending on the study. ${ }^{4,14}$ It is possible that the use of samples with few women and in which consumption of different substances is not differentiated is related to the lack of homogeneity.

One issue on which the current research seems to agree is the greater likelihood of a history of maltreatment and sexual abuse among female addicts attending treatment. While the overall rate of maltreatment and sexual abuse is high in addicted patients of both sexes, ${ }^{21,22}$ the incidence is much higher among women., ${ }^{3,6,23-25}$ Therefore, it is important to consider the impact of maltreatment and sexual abuse when establishing a specific profile of addicted women because those factors directly affect substance consumption and the course of treatment. ${ }^{21}$

Moreover, some studies are now examining potential gender differences severity and course of addiction for females compared with males, as well as gender differences in motivation for treatment, treatment efficacy, and therapeutic outcomes. The results are heterogeneous. While some studies have observed that women have a greater motivation for treatment, greater involvement in self-help activities and a better therapeutic outcome, ${ }^{8,10,26}$ other studies have reported that gender is not directly related to the adherence and/or completion of treatment. ${ }^{2,7,27,28}$ Additional studies are needed to better characterize the impact of addiction in females compared to males. Elucidation of

Fernández-Montalvo, J., López-Goñi, J. J., Azanza, P. y Cacho, R. (2014). Gender differences in drug-addicted patients in treatment. The American Journal on

Addictions, 23, 399-406

http://onlinelibrary.wiley.com/doi/10.1111/j.1521-0391.2013.12117.x/abstract 
these differences may contribute to the future development of more effective, genderspecific treatment strategies.

While some studies have demonstrated differences in the symptom profiles of women seeking outpatient treatment compared to men, an expanded, more comprehensive characterization is needed. Only in this way specific treatment programs can be implemented that are tailored to the needs of addicted women. In Spain, research traditionally had focused on how men fared in substance abuse treatment, with an important gap in gender differences. Therefore, the main objectives of this study were to determine the characteristics of a sample of addicted women undergoing treatment and to determine whether their profile differs from that of addicted men. To achieve these objectives, a group of addicted women entering outpatient treatment was compared with a group of addicted men in terms of various sociodemographic and consumption variables. Based on the literature, the main hypothesis of this study is that women will present a more severe substance abuse profile, with more psychological and adjustment consequences derived from their addictive behavior. However, men will demonstrate more legal problems related to drug abuse.

\section{Method}

The protocol for this study was approved by the ethics committees of the Public University of Navarra and of the Fundación Proyecto Hombre de Navarra.

\section{Participants}

The sample consists of 195 addicted patients (95 female and 100 male) who entered outpatient treatment at the Fundacion Proyecto Hombre de Navarra (Spain) between May 2010 and June 2012. This is a cognitive-behavioral intervention on an outpatient basis, aimed at abstinence. The main therapeutic techniques are related to stimulus control and in vivo exposure, as well as relapse prevention. Successful program

Fernández-Montalvo, J., López-Goñi, J. J., Azanza, P. y Cacho, R. (2014). Gender differences in drug-addicted patients in treatment. The American Journal on 
completion typically requires around 12 months, and it is achieved when a patient completes all therapeutic sessions. This program has shown effective in the treatment of addictions. $^{29}$

The current study's admission criteria were that the patients had to a) meet the diagnostic criteria of substance dependence according to the DSM-IV-TR; ${ }^{30} \mathrm{~b}$ ) be between 18 and 65 years old; c) receive outpatient treatment in the "Proyecto Hombre" treatment program; d) give their informed consent to participate in the study; and d) complete the two assessment sessions.

The mean age of the individuals included in the study was 36.2 years $(S D=9.9)$; the sample included 100 (51.3\%) men and 95 (48.7\%) women. The socioeconomic level was middle to lower-middle class. Most of the participants were unmarried (54.4\%) and had a primary education (52.3\%). The main substances that motivated treatment were alcohol (45.1\%) and cocaine (39\% of the sample), followed by other substances (e.g., heroin, cannabis, amphetamine, etc.) in smaller numbers (15.9\% of the sample).

\section{Assessment}

The EuropASI ${ }^{31}$ is the European version of the Addiction Severity Index. ${ }^{32}$ This tool yields interviewer severity ratings (ISR) and Composite Scores (CS). ISR assess the need for treatment in the following seven areas: a) general medical state; b) labor and economic situation; c) drug consumption; d) alcohol consumption; e) legal problems; f) family and social relationships; and g) psychiatric state. Severity scores range from 0 (no problem) to 9 (extreme problem) in each area, and the cut-off point for each area is 4. These areas are directly related to the severity of consumption. ${ }^{33}$ In this study we have also used the Composite Scores (CS) of the EuropASI. The CS were developed for research purposes; they are arithmetically-based indicators of current (last 30 days) problem severity and range between 0.00-1.00, with higher values denoting higher

Fernández-Montalvo, J., López-Goñi, J. J., Azanza, P. y Cacho, R. (2014). Gender differences in drug-addicted patients in treatment. The American Journal on 
degrees of severity. They assess the following nine areas: a) general medical state; b) economic situation; c) labor satisfaction; d) alcohol consumption; e) drug consumption; f) legal problems; g) family relationships; h) social relationships; and i) psychiatric state. The CS have been calculated according to the proposal by Koeter and Hartgers. ${ }^{34}$ The Spanish version of the EuropASI was developed by Bobes, González, Sáiz and Bousoño. ${ }^{35}$ In this study, ISR and CS have been used, because they offer complementary information. ${ }^{36}$ The short-term test-retest reliabilities of the ASI severity ratings have been reported to be greater than or equal to .92 for all domains. ${ }^{37}$ The alpha coefficients for the current sample were .70 for the ISR scores and .63 for the composite scores. Regarding specific scales, alpha coefficients were .81 (general medical scale), .78 (labor and economic situation), .80 (drug consumption), .86 (alcohol consumption), .88 (legal problems), .73 (family and social relationships), and .82 (psychiatric state).

Moreover, in this study some items of the EuropASI were used to obtain specific information about the presence of psychopathological problems in the sample (Psychiatric scale: items 2-4; 6, 7, 9, 10), as well as the level of adjustment in different areas: family and social relationships (Family and social scale: items 10b-18b), labor situation (Employment support scale: item 8), legal status (Legal scale: items 3-6, 11), and history of abuse (Family and social scale: items 18A-18C).

Procedure

Once the clinical sample was selected using the above described criteria, the assessment of the sample was carried out in two sessions before beginning the treatment. All patients were interviewed by clinical psychologists who had eight or more years of experience in treating addictions and in applying the EuropASI. Each session took place once a week for two weeks; the time interval between sessions was the same for each participant (one week). In the first session, data related to socio-

Fernández-Montalvo, J., López-Goñi, J. J., Azanza, P. y Cacho, R. (2014). Gender differences in drug-addicted patients in treatment. The American Journal on

Addictions, 23, 399-406

http://onlinelibrary.wiley.com/doi/10.1111/j.1521-0391.2013.12117.x/abstract 
demographic characteristics and drug consumption were collected using the EuropASI. In the second session, the presence of psychological symptoms and problems, as well as the maladjustment level, was assessed. After the assessment sessions, patients began the standard treatment of Proyecto Hombre for addiction.

Data Analyses

Descriptive analyses were conducted for all variables. Bivariate analyses were employed using $\chi^{2}$ or t-test statistics, depending on the nature of the variables studied. Regarding multivariate analysis, a logistic regression analysis (forward method) was carried out in order to know what specific factors were more relevant to differentiate between both groups studied. A difference of $p<.05$ was considered significant. Statistical analyses were carried out using SPSS (version 15.0 for Windows).

\section{Results}

Sociodemographic characteristics

The comparison between the men and women in sociodemographic characteristics are shown in Table 1. There was only one statistically significant difference according to gender. Eighty-four per cent of the sample was employed, although the women had a significantly lower employment rate than the men did.

\section{INSERT TABLE 1}

\section{Consumption variables}

Regarding the characteristics related to consumption, the main substance for which the subjects sought treatment was alcohol, followed by stimulants (cocaine and/or amphetamines) and other substances (e.g., heroin, cannabis and benzodiazepines). Gender differences were not observed in any case (Table 1). The age of consumption onset was approximately 18 years for alcohol and non-stimulant substances and approximately 22 years for stimulants, and there were no significant

Fernández-Montalvo, J., López-Goñi, J. J., Azanza, P. y Cacho, R. (2014). Gender differences in drug-addicted patients in treatment. The American Journal on

Addictions, 23, 399-406

http://onlinelibrary.wiley.com/doi/10.1111/j.1521-0391.2013.12117.x/abstract 
differences between the groups. Regarding the duration of use, the average was 20.3 years for alcohol, with a significantly longer duration for the men than for the women. No significant differences were observed for the remaining substances studied.

Regarding the severity of addiction (Table 2), a comparison of the men's and the women's EuropASI scores showed significant differences in both the Interviewer Severity Ratings (ISR; based on the evaluation team's subjective perceptions) and the Composite Scores (CS; based on the instrument's objective indicators). Specifically, the ISRs showed that the women had a significantly higher severity in areas related to medical issues, employment, family/social issues and psychological problems. In comparison, the men's scores showed more severe problems in the legal domain.

\section{INSERT TABLE 2}

The EuropASI CSs also exhibited important gender differences. The women exhibited greater severity than the men did in almost all of the instrument's domains: the medical, employment and finance, job satisfaction, family, social and psychological domains. The men had more problems than the women did only in the legal domain. In terms of alcohol and drug consumption, neither of the two types of EuropASI scores showed significant differences between the groups.

Psychopathological variables

Regarding associated psychopathology issues, the results indicated many differences between the men and women in the sample (Table 2). Specifically, the women had a higher rate of anxiety disorders, severe depressive symptoms, suicidal ideation symptoms and/or suicide attempts. Furthermore, a significantly higher number of women than men habitually used psychotropic drugs.

Variable adjustment

Fernández-Montalvo, J., López-Goñi, J. J., Azanza, P. y Cacho, R. (2014). Gender differences in drug-addicted patients in treatment. The American Journal on

Addictions, 23, 399-406

http://onlinelibrary.wiley.com/doi/10.1111/j.1521-0391.2013.12117.x/abstract 
The results obtained for the adjustment variables are shown in Table 3. All of the patients had high rates of maladjustment in different areas of daily life (e.g., family, social, labor, legal), and significant differences between the groups were observed in some domains. In the family domain, for example, the percentage of women who had problems with their mothers and children was significantly higher than the percentage of males who did. The same imbalance applied to the variables related to maladjustment in the workplace; a higher percentage of women than men reported not having had a permanent job in recent years.

\section{INSERT TABLE 3}

However, the males in the sample had a greater number of problems with the law, including significantly more instances of possession and/or drug trafficking and traffic offenses (mainly driving under the influence of alcohol) than the women.

Finally, it is noteworthy that more than half of the sample had suffered from some form of abuse. The women had a significantly higher victimization rate than the men for all types of abuse that were studied.

\section{Multivariate analysis}

Results from logistic regression analysis showed that the more relevant variables to differentiate between both groups studied were being a victim of abuse, three composite scores domains (economic situation, legal status and psychiatric state), one ISR scores domain (alcohol use) and the presence of anxiety problems. These six variables correctly classified $85.3 \%$ of the cases.

\section{INSERT TABLE 4}

From a clinical point of view, it is important to highlight that the variable "being a victim of abuse” by itself correctly classified $77.4 \%$ of the cases.

Fernández-Montalvo, J., López-Goñi, J. J., Azanza, P. y Cacho, R. (2014). Gender differences in drug-addicted patients in treatment. The American Journal on 


\section{Discussion}

The study of addiction from a gender perspective has flourished in recent years. ${ }^{2-}$ 5,7-,9 Nevertheless, the current scientific support for differential profiles of male and female addicted patients is far from clear. The importance of the present study is that it analyzes the specific profile of a sample of women $(n=95)$ who attended a specialized treatment program from a region in Northern Spain. Thus, the differential characteristics of addicted women can be assessed in a clinical setting.

Our results confirm the existence of a differential profile for addicted women and men. Most of the variables showed a significantly higher level of addiction severity in women than in men. The EuropASI scores, for example, reflect important differences between men and women in all areas except those related to patterns of alcohol and drug consumption. The women experienced more severe impacts in the medical, work, family, social and psychiatric areas than the men did. In contrast, the men had more severe legal problems than the women did. These results are consistent with previous studies that report greater clinical severity for addicted women and more severe legal problems for addicted men. ${ }^{7,8,19,29}$

The significant differences between men and women reappeared when the presenting psychopathological symptoms were analyzed. The women showed more comorbidities, reflected by a significantly higher number of anxiety problems, depressive disorders or suicidal ideation and suicide attempts. In fact, psychotropic drug use was significantly higher among the women than among the men. These results corroborate the trend found in the studies that have been conducted to date ${ }^{4,8,16}$ and confirm the increased presence of associated psychopathological symptomatology in addicted women compared with their male counterparts. These results could be related

Fernández-Montalvo, J., López-Goñi, J. J., Azanza, P. y Cacho, R. (2014). Gender differences in drug-addicted patients in treatment. The American Journal on 
to the higher prevalence rate of anxiety and depressive symptoms found in women by epidemiological studies with general population. ${ }^{38}$

Moreover, the rate of physical, psychological and sexual abuse in the sample of patients was high. More than half of the sample was subjected to some form of abuse in their lifetimes. There were significant gender differences in both the overall prevalence of abuse and in the specific analysis of the different types of abuse studied: physical, psychological and sexual abuse. The relationship between addiction and a history of abuse is not new. Several previous studies have found significant rates of maltreatment and sexual abuse in addicted patients, with figures averaging approximately $50 \%$ of the studied patients. ${ }^{21,22}$ This study supports such findings and the gender differences regarding the prevalence of the different types of maltreatment and abuse. .,6,23-25 $^{3}$ Therefore, the patient's history of physical, psychological or sexual abuse is an important variable to consider when establishing a specific profile of addicted women.

An interesting point to analyze is that the more severe profile found in this study in women versus men is inconsistent with general population based literature. Epidemiological studies consistently show higher prevalence of substance use and substance use disorders among men compared to women. ${ }^{38-40}$ According to the results obtained, women seem to be more reluctant to seek treatment and, when they decide to consult about their addiction problems, they are in a more severe situation and with a higher impact in the main areas of life. In this way, some studies have shown that women are more likely than men to face multiple barriers to accessing substance abuse treatment. ${ }^{2,5,8}$ Moreover, women tend to seek care in mental health or primary care settings rather than in specialized treatment programs. ${ }^{5}$ Anyway, this is only a potential explanation of the results obtained and it should be analyzed in future studies.

Fernández-Montalvo, J., López-Goñi, J. J., Azanza, P. y Cacho, R. (2014). Gender differences in drug-addicted patients in treatment. The American Journal on

Addictions, 23, 399-406

http://onlinelibrary.wiley.com/doi/10.1111/j.1521-0391.2013.12117.x/abstract 
This study has several limitations that should be considered. The first is related to the evaluated sample. Although we included a relatively large number of women $(\mathrm{N}$ =95), it would be desirable to replicate these studies with a larger sample size. This would allow the creation of a profile of addicted women while taking into account other important factors, such as the type of substance consumed. The heterogeneity observed among the different studies may relate precisely to the pooling of different substances in the samples studied. Moreover, our study included women who sought treatment at a specialized center. Undoubtedly, this creates a bias that prevents generalizing the results to addicted women in general. Women are more reluctant than men to seek treatment, mainly because of the social stigma of addiction. Therefore, the profile we present refers specifically to women in treatment, not to addicted women in general. Finally, this is a correlational study that does not have into consideration causal factors of the differences. Future studies should consider other factors, as social influence, which may explain why women suffer from more severe maladjustment than men.

In any case, the data found in this study support the notion that addicted women in treatment have a profile that distinguishes them from addicted men. Therefore, it is necessary to continue to study addiction from a gender perspective. Beyond the results found in most studies with samples consisting mainly of male patients, it is useful to describe the specific characteristics of addicted women. This will allow a better understanding of the factors that increase resistance to treatment and an adaptation of existing intervention programs to meet the specific needs of this group.

Fernández-Montalvo, J., López-Goñi, J. J., Azanza, P. y Cacho, R. (2014). Gender differences in drug-addicted patients in treatment. The American Journal on

Addictions, 23, 399-406

http://onlinelibrary.wiley.com/doi/10.1111/j.1521-0391.2013.12117.x/abstract 


\section{References}

1. Brady KT, Back SE, Greenfield S. Women and addiction: A comprehensive handbook. New York: Guildford Press; 2009.

2. Greenfield SF, Brooks AJ, Gordon SM, et al. Substance abuse treatment entry, retention and outcome in women: A review of the literature. Drug Alcohol Depend. 2009;86:1-21.

3. Walitzer KS, Dearing RL. Gender differences in alcohol and substance use relapse. Clin Psychol Rev. 2006;26:126-148.

4. Bravo de Medina R, Echeburúa E, Aizpiri J. Diferencias de sexo en la dependencia del alcohol: dimensiones de personalidad, características psicopatológicas y trastornos de personalidad [Gender differences in alcohol dependence: Personality variables, psychopthological profile and personality disorders]. Psicothema. 2008;20:218-223.

5. Green CA. Gender and use of substance abuse treatment services. Alcohol Res Health. 2006;29:55-62.

6. Greenfield SF, Back SE, Lawson K, et al. Substance abuse in women. Psychiatr Clin North Amer 2010;33:339-355.

7. Hser YI, Huang D, Teruya C, et al. Gender comparisons of drug abuse treatment outcomes and predictors. Drug and Alcohol Depend. 2003;72:255-264.

8. Najavits LM, Lester KM. Gender differences in cocaine dependence. Drug and Alcohol Depend. 2008;97:190-194.

9. Wetherington CL. Sex-gender differences in drug abuse: a shift in the burden of proof. Exp Clin Psychopharmacol. 2007;15:411-417.

10. Grella CE, Scott CK, Foss MA. Gender differences in long-term drug treatment outcomes in Chicago PETS. J Subst Abus Treat. 2005;28:S3-S12.

Fernández-Montalvo, J., López-Goñi, J. J., Azanza, P. y Cacho, R. (2014). Gender differences in drug-addicted patients in treatment. The American Journal on

Addictions, 23, 399-406 http://onlinelibrary.wiley.com/doi/10.1111/j.1521-0391.2013.12117.x/abstract 
11. Fox HC, Sinha R. Sex differences in drug-related stress-system changes: Implications for treatment in substance-abusing women. Harv Rev Psychiatr. 2009;17:103-119.

12. Fattore L, Fadda P, Fratta W. (2009). Sex differences in the self-administration of cannabinoids and other drugs of abuse. Psychoneuroendocrinology. 2009;34S:S227S236.

13. Lynch WJ, Roth ME, Carroll ME. Biological basis of sex differences in drug abuse: preclinical and clinical studies. Psychopharmacology. 2002;164:121-137.

14. Picci RL, Vigna-Taglianti F, Oliva F, et al. Personality disorders among patients accessing alcohol detoxification treatment: prevalence and gender differences. Compr Psychiat. 2012;53:355-363.

15. Colpaert K, De Maeyer J, Broekaert E, et al. Impact of addiction severity and psychiatric comorbidity on the quality of life of alcohol-, drug- and dual-dependent persons in residential treatment. Eur Addict Res. 2013;19:173-183.

16. Johnson ME, Yep MJ, Brems C, et a. Relationship among gender, depression, and needle sharing in a sample of injection drug users. Psychol Addict Behav. 2002;16:338-341.

17. Landa N, Fernandez-Montalvo J, López-Goñi JJ, et al. Comorbilidad psicopatológica en el alcoholismo: Un estudio descriptivo [Psychopathological comorbidity in alcoholism: A descriptive study]. I J Clin Health Psychol. 2006;6:253-269.

18. Lorea I, Fernandez-Montalvo J, López-Goñi JJ, et al. (2009). Adicción a la cocaína y trastornos de personalidad: un estudio con el MCMI-II [Cocaine addiction and personality disorders: A study with the MCMI-II]. Adicciones. 2009;21:57-63.

Fernández-Montalvo, J., López-Goñi, J. J., Azanza, P. y Cacho, R. (2014). Gender differences in drug-addicted patients in treatment. The American Journal on

Addictions, 23, 399-406

http://onlinelibrary.wiley.com/doi/10.1111/j.1521-0391.2013.12117.x/abstract 
19. Miquel L, Roncero kC, López-Ortiz C, et al. Diferencias de género epidemiológicas y diagnósticas según eje I en pacientes con patología dual [Epidemiological and diagnostic axis I gender differences in dual diagnosis patients]. Adicciones. 2011;23:165-172.

20. Storbjörk J. Gender differences in substance use, problems, social situation and treatment experiences among clients entering addiction treatment in Stockholm. Nordic Studies on Alcohol and Drugs. 2011;28:185-209.

21. Fernández-Montalvo J, López-Goñi JJ, Arteaga A. Violent behaviours in drug addiction: Differential profiles of drug-addicted patients with and without violence problems. J Interpers Violence. 2012;27:142-157.

22. Schneider R, Cronkite R,Timko C. (2008). Lifetime physical and sexual abuse and substance use treatment outcome in men. J Subst Abus Treat. 2008;35:353-361.

23. Liebschutz J, Savetsky JB, Saits R, et al. The relationship between sexual and physical abuse and substance abuse consequences. J Subst Abus Treat. 2002;22:121128.

24. Min M, Farkas K, Minnes S, et al. Impact of chilhood abuse and neglect on substance abuse and psychological distress in adulthood. J Trauma Stress. 2007;20:833-844.

25. Sacks JY, McKendrick K, Banks S. The impact of early trauma and abuse on residential substance abuse treatment outcomes for women. J Subst Abus Treat. 2008;34:90-100.

26. López-Goñi JJ, Fernández-Montalvo J, Illescas C, et al. (2008). Determining sociodemographic predictors of treatment dropout: results in a therapeutic community. $I J$ Soc Welf. 2008;17:374-378.

Fernández-Montalvo, J., López-Goñi, J. J., Azanza, P. y Cacho, R. (2014). Gender differences in drug-addicted patients in treatment. The American Journal on

Addictions, 23, 399-406

http://onlinelibrary.wiley.com/doi/10.1111/j.1521-0391.2013.12117.x/abstract 
27. Fernández-Montalvo J, López-Goñi J, Illescas C, et al. Relapse precipitants in addictions: Results in a therapeutic community. J Addict Dis. 2007;26:55-61.

28. Fernández-Montalvo J, López-Goñi JJ, Illescas C, et al. Evaluation of a therapeutic community treatment program: A long-term follow-up study in Spain. Subst Use Misuse. 2008;43:1362-1377.

29. Fernández-Montalvo J, López-Goñi JJ. Comparison of completers and dropouts in psychological treatment for cocaine addiction. Addict Res Theory. 2010;18:433-441.

30. American Psychiatric Association. Diagnostic and Statistical Manual of Mental Disorders, Fourth Edition, Text Revision (DSM-IV-TR). Washington DC: American Psychiatric Association; 2000.

31. Kokkevi A, Hartgers C. (1995). European adaptation of a multidimensional assessment instrument for drug and alcohol dependence. Eur Addict Res. 1995;1:208-210.

32. McLellan AT, Luborsky L, Woody GE, et al. An improved diagnostic evaluation instrument for substance abuse patients: The Addiction Severity Index. J Nerv Ment Dis. 1908;168:26-33.

33. López-Goñi JJ, Fernández-Montalvo J, Menéndez JC, et al. Group and individual change in the treatment of drug addictions: A follow-up study in therapeutic communities. Span J Psychol. 2010;13:906-913.

34. Koeter MWJ, Hartgers C. European addiction severity index europasi. Cost a6. Preliminary procedure for the computation of the europasi composite scores. Amsterdam: The Amsterdam Institute for Addiction Research; 1997.

35. Bobes J, González MP, Sáiz PA, et al. Índice europeo de severidad de la adicción: EuropASI. Versión española [European Index of Addiction Severity: EuropASI.

Fernández-Montalvo, J., López-Goñi, J. J., Azanza, P. y Cacho, R. (2014). Gender differences in drug-addicted patients in treatment. The American Journal on

Addictions, 23, 399-406

http://onlinelibrary.wiley.com/doi/10.1111/j.1521-0391.2013.12117.x/abstract 
Spanish version]. Paper presented at the Actas de la IV Reunión Interregional de Psiquiatría: 1996.

36. López-Goñi JJ, Fernández-Montalvo J, Arteaga A. Predictive validity of the EuropASI: Clinical diagnosis or composite scoring? J Subst Abus Treat. 2012;42:392-399.

37. McLellan AT, Luborsky L, Cacciola J, et al. New data from the Addiction Severity Index. Reliability and validity in three centers. J Nerv Ment Dis. 1985;173:412-423.

38. Frank E. Gender and its effects on psychopathology. American Psychiatric Publishing: Washington; 2000.

39. Merikangas KR, McClair VL. Epidemiology of substance use disorders. Hum Genet. 2012;131:779-789.

40. Observatorio Español de la Droga y las Toxicomanías. Informe 2011. Situación y tendencias de los problemas de drogas en España [Report 2011. Status and trends of drug problems in Spain]. Ministerio de Sanidad, Política Social e Igualdad: Madrid; 2011.

Fernández-Montalvo, J., López-Goñi, J. J., Azanza, P. y Cacho, R. (2014). Gender differences in drug-addicted patients in treatment. The American Journal on Addictions, 23, 399-406 http://onlinelibrary.wiley.com/doi/10.1111/j.1521-0391.2013.12117.x/abstract 
Table 1. Socio-demographic and consumption characteristics of the sample

\begin{tabular}{|c|c|c|c|c|c|c|c|}
\hline & \multicolumn{2}{|c|}{$\begin{array}{c}\text { Total } \\
(\mathrm{N}=195)\end{array}$} & \multicolumn{2}{|c|}{$\begin{array}{l}\text { Females } \\
(n=95)\end{array}$} & \multicolumn{2}{|c|}{$\begin{array}{c}\text { Males } \\
(n=100)\end{array}$} & \multirow[t]{2}{*}{$t$} \\
\hline & Mean & $( \pm$ SD) & Mean & $( \pm$ SD) & Mean & $( \pm$ SD) & \\
\hline Mean age & 36.2 & $(9.9)$ & 35.0 & $(9.0)$ & 37.3 & $(10.5)$ & 1.6 \\
\hline \multicolumn{8}{|l|}{ Age at first consumption } \\
\hline Alcohol & 18.1 & $(5.2)$ & 18.9 & $(5.2)$ & 17.4 & $(5.2)$ & 1.3 \\
\hline Cocaine & 22.8 & (5.7) & 22.5 & $(6.2)$ & 23.0 & (5.5) & 0.4 \\
\hline Others (heroin, cannabis, etc.) & 17.1 & (4.5) & 17.1 & (5.5) & 17.1 & (3.3) & 0 \\
\hline \multicolumn{8}{|l|}{ Years of consumption } \\
\hline Alcohol & 20.3 & (11.4) & 16.8 & (10.5) & 23.6 & $(11.4)$ & $2.7^{*}$ \\
\hline Cocaine & 5.6 & $(5.5)$ & 7.3 & $(7.3)$ & 4.7 & $(4.1)$ & 1.6 \\
\hline \multirow[t]{2}{*}{ Others (heroin, cannabis, etc.) } & 11.4 & $(7.2)$ & 10.6 & (9.1) & 12.2 & (5.6) & 0.5 \\
\hline & $\mathbf{N}$ & $(\%)$ & $\mathbf{n}$ & $(\%)$ & $\mathbf{n}$ & $(\%)$ & \multirow[b]{2}{*}{$X^{2}$} \\
\hline Marital status & & & & & & & \\
\hline Single & 106 & $(54.4 \%)$ & 49 & $(51.6 \%)$ & 57 & $(57 \%)$ & \\
\hline Married & 50 & $(25.6 \%)$ & 28 & $(29.5 \%)$ & 22 & $(22 \%)$ & 1.4 \\
\hline Divorced & 39 & $(20.0 \%)$ & 18 & $(18.9 \%)$ & 21 & $(21 \%)$ & \\
\hline \multicolumn{8}{|l|}{ Education } \\
\hline Primary school & 102 & $(52.3 \%)$ & 44 & $(46.3 \%)$ & 58 & $(58 \%)$ & \multirow{3}{*}{4.7} \\
\hline Secondary school & 76 & $(39.0 \%)$ & 39 & $(41.1 \%)$ & 37 & $(37 \%)$ & \\
\hline University & 17 & $(8.7 \%)$ & 12 & $(12.6 \%)$ & 5 & $(5 \%)$ & \\
\hline \multicolumn{8}{|l|}{ Employment situation } \\
\hline Employed & 164 & $(84.1 \%)$ & 68 & $(71.6 \%)$ & 96 & $(96 \%)$ & \multirow{3}{*}{$22.0^{* *}$} \\
\hline Unemployed & 21 & $(10.8 \%)$ & 19 & $(20.0 \%)$ & 2 & $(2 \%)$ & \\
\hline Other (student, retired, etc.) & 10 & $(5.1 \%)$ & 8 & $(8.4 \%)$ & 2 & $(2 \%)$ & \\
\hline \multicolumn{8}{|c|}{ Substance that motivated treatment } \\
\hline Alcohol & 88 & $(45.1 \%)$ & 45 & $(47.4 \%)$ & 43 & $(43 \%)$ & \multirow{3}{*}{4.1} \\
\hline Cocaine & 76 & $(39.0 \%)$ & 31 & $(32.6 \%)$ & 45 & $(45 \%)$ & \\
\hline Others (heroin, cannabis, etc.) & 31 & $(15.9 \%)$ & 19 & $(20.0 \%)$ & 12 & $(12 \%)$ & \\
\hline
\end{tabular}

${ }^{*} p<.01 ; * *<.001$

Fernández-Montalvo, J., López-Goñi, J. J., Azanza, P. y Cacho, R. (2014). Gender differences in drug-addicted patients in treatment. The American Journal on

Addictions, 23, 399-406

http://onlinelibrary.wiley.com/doi/10.1111/j.1521-0391.2013.12117.x/abstract 
Table 2. Comparisons in Interviewer Severity Ratings (ISR), Composite Scores (CS) of EuropASI and psychological problems

\begin{tabular}{|c|c|c|c|c|c|c|c|c|}
\hline \multirow[b]{2}{*}{ EuropASI (ISR) } & \multicolumn{2}{|c|}{$\begin{array}{c}\text { Total } \\
(\mathrm{N}=195)\end{array}$} & \multicolumn{2}{|c|}{$\begin{array}{c}\text { Females } \\
(\mathrm{n}=95)\end{array}$} & \multicolumn{2}{|c|}{$\begin{array}{c}\text { Males } \\
(n=100)\end{array}$} & \multirow[t]{2}{*}{$t$} & \multirow[t]{2}{*}{ d.f. } \\
\hline & $\mathbf{M}$ & $( \pm \mathrm{SD})$ & $\mathbf{M}$ & $( \pm \mathrm{SD})$ & $\mathbf{M}$ & ( \pm SD) & & \\
\hline Medical & 2.0 & $(1.6)$ & 2.3 & $(1.8)$ & 1.8 & $(1.3)$ & $2.5^{*}$ & 170.3 \\
\hline Employment/Support & 2.6 & (1.8) & 3.1 & (1.9) & 2.2 & (1.6) & $3.8^{* * *}$ & 178.7 \\
\hline Alcohol use & 3.8 & $(2.2)$ & 3.6 & $(2.2)$ & 3.9 & (2.1) & 1.0 & 188.0 \\
\hline Drugs use & 3.5 & $(2.2)$ & 3.7 & (2.3) & 3.4 & (2.1) & 0.7 & 187.0 \\
\hline Legal & 1.5 & (1.4) & 1.2 & (1.3) & 1.7 & (1.5) & $2.3^{*}$ & 186.0 \\
\hline Family/Social & 4.0 & (1.8) & 4.5 & (1.7) & 3.6 & (1.7) & $3.9 * * *$ & 187.0 \\
\hline Psychiatric & 3.5 & $(1.8)$ & 4.1 & $(1.7)$ & 2.9 & $(1.7)$ & $4.8 * * *$ & 188.0 \\
\hline \multicolumn{9}{|l|}{ EuropASI (CS) } \\
\hline Medical & .24 & $(.27)$ & .30 & $(.29)$ & .19 & $(.24)$ & $2.8^{* *}$ & 184.2 \\
\hline Economic situation & .46 & $(.47)$ & .59 & $(.47)$ & .33 & (.43) & $3.9 * * *$ & 189.9 \\
\hline Labor satisfaction & .30 & $(.31)$ & .37 & $(.31)$ & .24 & $(.30)$ & $3.1^{* *}$ & 192.0 \\
\hline Alcohol & .30 & $(.25)$ & .28 & $(.26)$ & .32 & (.23) & 1.3 & 193.0 \\
\hline Drug use & .13 & (.13) & .13 & (.14) & .13 & $(.11)$ & 0.3 & 193.0 \\
\hline Legal & .09 & $(.18)$ & .06 & (.15) & .12 & (.19) & $2.6^{*}$ & 185.5 \\
\hline Family & .30 & $(.25)$ & .36 & $(.25)$ & .25 & $(.23)$ & $3.4^{* *}$ & 193.0 \\
\hline Others & .18 & $(.19)$ & .21 & $(.20)$ & .14 & $(.17)$ & $2.5^{*}$ & 183.5 \\
\hline Psychiatric & .25 & $(.20)$ & .31 & $(.21)$ & .19 & $(.18)$ & $4.2^{* * *}$ & 193.0 \\
\hline $\begin{array}{l}\text { Psychopathological } \\
\text { symptoms }\end{array}$ & $\mathbf{N}$ & (\%) & $\mathbf{n}$ & $(\%)$ & $\mathbf{n}$ & (\%) & $X^{2}$ & d.f. \\
\hline Anxiety problems & 134 & $(68.7 \%)$ & 79 & $(83.2 \%)$ & 55 & (55\%) & $18.0^{* * *}$ & 1 \\
\hline Severe depression & 115 & (59.0\%) & 69 & $(72.6 \%)$ & 46 & $(46 \%)$ & $8.1^{* *}$ & 1 \\
\hline Suicide ideation & 90 & (46.1\%) & 55 & (57.9\%) & 35 & (35\%) & $10.3^{* *}$ & 1 \\
\hline $\begin{array}{l}\text { Problems of violence } \\
\text { control }\end{array}$ & 76 & $(39.0 \%)$ & 39 & (41.1\%) & 37 & (37\%) & 0.3 & 1 \\
\hline Suicide attempts & 45 & $(23.1 \%)$ & 33 & (34.7\%) & 12 & $(12 \%)$ & $14.2^{* * *}$ & 1 \\
\hline Hallucinations & 32 & $(16.4 \%)$ & 15 & $(15.8 \%)$ & 17 & $(17 \%)$ & 0.0 & 1 \\
\hline \multicolumn{9}{|l|}{ Other indicators } \\
\hline $\begin{array}{l}\text { Psychological disability } \\
\text { allowance }\end{array}$ & 3 & $(1.5 \%)$ & 3 & $(3.2 \%)$ & 0 & $(--)$ & 3.2 & 1 \\
\hline $\begin{array}{l}\text { Psychopharmacological } \\
\text { treatments }\end{array}$ & 96 & $(49.2 \%)$ & 54 & $(56.8 \%)$ & 42 & $(42 \%)$ & $4.3^{*}$ & 1 \\
\hline
\end{tabular}

${ }^{*} p<.05 ; * * p<.01 ; * * * p<.001$

Fernández-Montalvo, J., López-Goñi, J. J., Azanza, P. y Cacho, R. (2014). Gender differences in drug-addicted patients in treatment. The American Journal on

Addictions, 23, 399-406

http://onlinelibrary.wiley.com/doi/10.1111/j.1521-0391.2013.12117.x/abstract 
Table 3. Comparisons in maladjustment variables

\begin{tabular}{|c|c|c|c|c|c|}
\hline & & $\begin{array}{c}\text { Total } \\
(\mathbf{N}=195) \\
N \quad(\%)\end{array}$ & $\begin{array}{c}\text { Females } \\
(\mathrm{n}=95) \\
\mathrm{n}(\%)\end{array}$ & $\begin{array}{c}\text { Males } \\
(\mathbf{n}=\mathbf{1 0 0}) \\
\mathrm{n}(\%)\end{array}$ & $\mathbf{X}^{2}$ \\
\hline \multicolumn{6}{|c|}{ Family maladjustment } \\
\hline \multirow{5}{*}{$\begin{array}{l}\text { Problems } \\
\text { with }\end{array}$} & Mother & $74(37.9 \%)$ & $45(47.4 \%)$ & $29(29 \%)$ & $6.9 *$ \\
\hline & Father & $70(35.9 \%)$ & 37 (38.9\%) & $33(33 \%)$ & 0.7 \\
\hline & Brothers/sisters & $76(38.9 \%)$ & $40(42.1 \%)$ & $36(36 \%)$ & 0.7 \\
\hline & Sexual partner & $122(62.6 \%)$ & $64(67.4 \%)$ & $58(58 \%)$ & 1.8 \\
\hline & Sons/daughters & $18(9.2 \%)$ & $15(15.8 \%)$ & $3(3 \%)$ & $9.5^{*}$ \\
\hline \multicolumn{6}{|c|}{ Social maladjustment } \\
\hline \multirow{3}{*}{$\begin{array}{l}\text { Problems } \\
\text { with }\end{array}$} & Close friends & $53(27.2 \%)$ & $29(30.5 \%)$ & $24(24 \%)$ & 1.05 \\
\hline & Neighbors & $22(11.3 \%)$ & $9(9.5 \%)$ & $13(13 \%)$ & 0.6 \\
\hline & Work colleagues & $59(30.2 \%)$ & $24(25.3 \%)$ & $35(35 \%)$ & 2.2 \\
\hline \multicolumn{6}{|c|}{ Labor maladjustment } \\
\hline \multicolumn{2}{|c|}{$\begin{array}{l}\text { Lacking a permanent job } \\
\text { during the previous } 3 \text { years }\end{array}$} & $31(15.9 \%)$ & 28 (29.5\%) & $3(3 \%)$ & $25.5^{* *}$ \\
\hline \multicolumn{6}{|c|}{ Legal maladjustment } \\
\hline \multirow{5}{*}{$\begin{array}{l}\text { Charged } \\
\text { with }\end{array}$} & $\begin{array}{l}\text { Drug possession and } \\
\text { trafficking crime }\end{array}$ & $33(17.0 \%)$ & $8(8.5 \%)$ & $25(25 \%)$ & $9.3^{*}$ \\
\hline & Crimes against property & $20(10.3 \%)$ & $8(8.5 \%)$ & $12(12 \%)$ & 1.2 \\
\hline & Violent crimes & $4(2.1 \%)$ & $1(1.1 \%)$ & $3(3 \%)$ & 0.9 \\
\hline & $\begin{array}{l}\text { Disorderly conduct } \\
\text { crime }\end{array}$ & $5(2.6 \%)$ & $1(1.1 \%)$ & $4(4 \%)$ & 1.7 \\
\hline & Driving-related crime & $36(18.6 \%)$ & $9(9.6 \%)$ & $27(27 \%)$ & $9.7 *$ \\
\hline \multicolumn{2}{|c|}{ Victim of abuse } & $110(56.4 \%)$ & $74(77.9 \%)$ & $36(36 \%)$ & $34.8 * *$ \\
\hline \multirow{3}{*}{$\begin{array}{l}\text { Type of } \\
\text { abuse }\end{array}$} & Psychological & $98(50.3 \%)$ & $65(68.4 \%)$ & $33(33 \%)$ & $24.5^{* *}$ \\
\hline & Physical & $63(32.3 \%)$ & $53(55.8 \%)$ & $10(10 \%)$ & $46.7 * *$ \\
\hline & Sexual & 37 (19.0\%) & $34(35.6 \%)$ & $3(3 \%)$ & $34.1 * *$ \\
\hline
\end{tabular}

${ }^{*} p<.01 ; * * p<.001$

Fernández-Montalvo, J., López-Goñi, J. J., Azanza, P. y Cacho, R. (2014). Gender differences in drug-addicted patients in treatment. The American Journal on

Addictions, 23, 399-406

http://onlinelibrary.wiley.com/doi/10.1111/j.1521-0391.2013.12117.x/abstract 
Table 4. Results of the logistic regression analysis (forward method)

\begin{tabular}{lcccccc}
\hline \multicolumn{1}{c}{ Variables } & B & SE & Wald & P & OR & $\mathbf{9 5 \% ~ C I ~}$ \\
\hline Victim of abuse & & & 30.6 & .000 & & \\
$\quad$ Psychological & -4.27 & 1.0 & 18.6 & .000 & 0.01 & $0.00-0.10$ \\
$\quad$ Physical & -4.01 & 1.0 & 15.4 & .000 & 0.02 & $0.00-0.13$ \\
$\quad$ Sexual & -1.5 & 1.1 & 1.9 & .162 & 0.22 & $0.03-1.84$ \\
\hline CS Economic situation & 1.20 & 0.5 & 5.9 & .015 & 3.31 & $1.27-8.66$ \\
\hline CS Legal & -5.07 & 1.6 & 10.2 & .001 & 0.006 & $0.00-0.14$ \\
\hline CS Psychiatric & 3.38 & 1.3 & 6.5 & .011 & 29.4 & $2.19-393.16$ \\
\hline ISR Alcohol use & -0.45 & 0.1 & 13.9 & .000 & 0.63 & $0.49-0.80$ \\
\hline Anxiety problems & -1.38 & 0.5 & 7.3 & .007 & 0.63 & $0.49-0.80$ \\
\hline Constant & 4.43 & 1.2 & 13.6 & .000 & 84.6 & \\
\hline
\end{tabular}

$\mathrm{CS}=$ Composite Scores

ISR = Interviewer Severity Ratings

B: coefficient for the constant; SE: standard error; OR: odds ratio; CI: confidence interval

Fernández-Montalvo, J., López-Goñi, J. J., Azanza, P. y Cacho, R. (2014). Gender differences in drug-addicted patients in treatment. The American Journal on

Addictions, 23, 399-406

http://onlinelibrary.wiley.com/doi/10.1111/j.1521-0391.2013.12117.x/abstract 


\section{Acknowledgements}

This study was supported by a grant from the Health Department of the Government of Navarra, Spain (Res. 359/2012). The authors thank the "Proyecto Hombre de Navarra" programme staff for their help in assessing the clinical sample.

\section{Declaration of interests}

The authors report no conflicts of interest. The authors alone are responsible for the content and writing of this paper.

Fernández-Montalvo, J., López-Goñi, J. J., Azanza, P. y Cacho, R. (2014). Gender differences in drug-addicted patients in treatment. The American Journal on Addictions, 23, 399-406 http://onlinelibrary.wiley.com/doi/10.1111/j.1521-0391.2013.12117.x/abstract 